\title{
The Effect of Work Motivation on Elementary School Teachers' Performance
}

\author{
Edy $^{1 *)}$, Edi Harapan ${ }^{2}$, Tahrun $^{2}$
}

\author{
${ }^{1}$ SD Negeri 5 Makarti Jaya \\ ${ }^{2}$ Universitas PGRI Palembang \\ *Corresponding author. Email: jhoniedijhoni@gmail.com
}

\begin{abstract}
This study aims to determine: 1) the role of teachers in the implementation of the 2013 curriculum, 2) the determinants of the 2013 curriculum implementation, 3) the optimization of the role of teachers in the curriculum 2013. The results showed that the role of teachers at SD Negeri 1 Rantau Sialang in implementing the 2013 curriculum, namely teachers as implementers, adapters, curriculum developers, and curriculum researchers. The teacher is not only the implementer of the curriculum but also the alignment of the curriculum with the characteristics and needs of students and regional needs. The supporting factors in the implementation of the 2013 Curriculum at SD Negeri 1 Rantau Sialang include the availability of facilities and infrastructure such as syllabus, lesson plans, teacher handbooks, and student textbooks. Inhibiting factor, namely the unpreparedness of the 2013 Curriculum. This is because there are still many obstacles and obstacles. However, SD Negeri 1 Rantau Sialang itself is ready or not ready to implement the 2013 Curriculum in compliance with the orders of the Ministry of Education and Culture. Implementation of the 2013 Curriculum can optimize the role of teachers in SD Negeri 1 Rantau Sialang. This must be adapted to the material to be taught and the conditions of the students themselves when participating in the teaching and learning process.
\end{abstract}

Keywords: Work Motivation, Teacher Performance, Elementary School

\section{INTRODUCTION}

Education plays a critical role in forming personalities and improving human capital. As a result, the government is committed to providing high-quality education. The quality of education determines the dignity or progress of a nation. By looking at the quality of education of a nation/country, one will be able to estimate the country's ranking among countries in the world. A developed nation will always pay great attention to the world of education, by making various efforts to improve the quality of education, such as increasing the education budget, holding various competitions in the educational aspect, or sending the nation's young people to study in other countries. These various efforts are made because of the awareness of the importance of education, the belief that a nation that neglects education will become an underdeveloped nation, which will be unable to compete with other nations.

Sutrisno says that every organization certainly wants to achieve its goals [1]. This goal is achieved through the feelings of the people involved in it are very important. To move people to fit what the organization wants, it must be understood that the motivation of the humans who work in the organization, because this motivation determines people's behavior for work, or in other words, behavior is the simplest reflection of motivation.

In Indonesian contexts, there are some factors that influence teacher work performance [2], and Mulyasa studies show that work motivation does influence teacher work performance [3]. Sardiman backed it up when it came to the factors that influence a teacher's success [4].

Basically, motivation can come from a person or what is often known as internal motivation and can also come from outside a person or also called external motivation. These motivational factors can have a positive or negative impact on a teacher. According to Mangkunegara said that motivation is formed from the attitude of employees in dealing with work situations in the company (situation) [5]. Motivation is the condition or energy that moves employees who are directed or aimed at achieving the goals of the company organization. It is the employee's pro and positive mental attitude towards work situations that strengthens their work motivation to achieve maximum performance.

If a teacher is trustworthy, committed to teaching tasks, masters and develops learning materials, discipline, innovative in teaching, cooperation with all school members, leadership, good personality, 
truthful and objective, and accountability, the teacher's performance will be good [6]. Principals must be able to influence all people involved in the education process, particularly teachers, in order to achieve school goals and quality [7], because one important factor in improving the education quality is educators or teachers [8].

Teacher's performance is the work achieved by a teacher in carrying out his duties and responsibilities in educational institutions to achieve educational goals [9]. Then, a motivation is important in organizations because it increases employee productivity and allows goals to be met more efficiently [10]. So, the main problem in this study can be formulated "Is there any effect of work motivation on teacher performance in SD Negeri Sekecamatan Makarti Jaya, Banyuasin Regency?" enhancement.

\section{METHODS}

This research was conducted at the State Elementary School of Makarti Jaya Sub-district, Banyuasin Regency from October to November 2020. This school was chosen by researchers because of several considerations, i.e. the school has sufficient criteria for research. The population in this study were the teachers who taught at SD Negeri Sekekarti Jaya, Banyuasin Regency. The sampling technique in this study using cluster sampling, which consists of 19 schools. But only 11 schools were researched. The technique of collecting data was carried out by observation, documentation, and questionnaires.

The questionnaire that has been compiled is validated by three validators after being declared valid, the next step is to do a questionnaire trial with 30 experimental respondents. From the test results, all items are declared valid and reliable, so that this questionnaire can be used for further research.

\section{RESULTS AND DISCUSSION}

Before the analysis was carried out, all data were subjected to the analysis requirements test, namely the normality test, linearity test, and multi-culinary test. The test results of all data meet the elements of the analysis requirements. The next step is to do a determination test, a significance test, and a simple regression test.

The hypothesis proposed in this study is the effect of work motivation on teacher performance. The results of the analysis can be seen in the following table
Table 1. Result of the Coefficient of Determination Work Motivation Variable $\left(\mathbf{X}_{1}\right)$ Against Teacher Performance (Y)

\begin{tabular}{|l|c|c|c|c|}
\hline \multicolumn{5}{|c|}{ Model Summary } \\
\hline $\begin{array}{l}\text { Mo } \\
\text { del }\end{array}$ & $\mathrm{R}$ & $\begin{array}{c}\mathrm{R} \\
\text { Squar } \\
\mathrm{e}\end{array}$ & $\begin{array}{c}\text { Adjusted } \\
\text { R Square }\end{array}$ & $\begin{array}{c}\text { Std. } \\
\text { Error } \\
\text { of the } \\
\text { Estim } \\
\text { ate }\end{array}$ \\
\hline 1 & $0,342^{\mathrm{a}}$ & 0,117 & 0,112 & 6,882 \\
\hline \multicolumn{4}{|c|}{ a. Predictors: (Constant), Working Motivation } \\
\hline
\end{tabular}

Based on the results in table 1, the calculation of the coefficient of determination obtained Rsquare value of 0.117 . This means that the magnitude of the influence of work motivation on the performance of SDN Makarti Jaya District teachers is $11.7 \%$, the remaining $88.3 \%$ is influenced by other factors which are not variables in this study.

The significance analysis obtained values of $4.635>t_{\text {table }} 1.286$ and $0.000<0.05$. This proves that work motivation has a significant effect on the performance of elementary school teachers. Thus, $\mathrm{H}_{0}$ is rejected and accepts $\mathrm{H}_{\mathrm{a}}$. Overall, it can be seen in the following table:

Table 2. Result of t-test Analysis

Work Motivation Variable $\left(\mathrm{X}_{1}\right)$ Against Teacher Performance (Y)

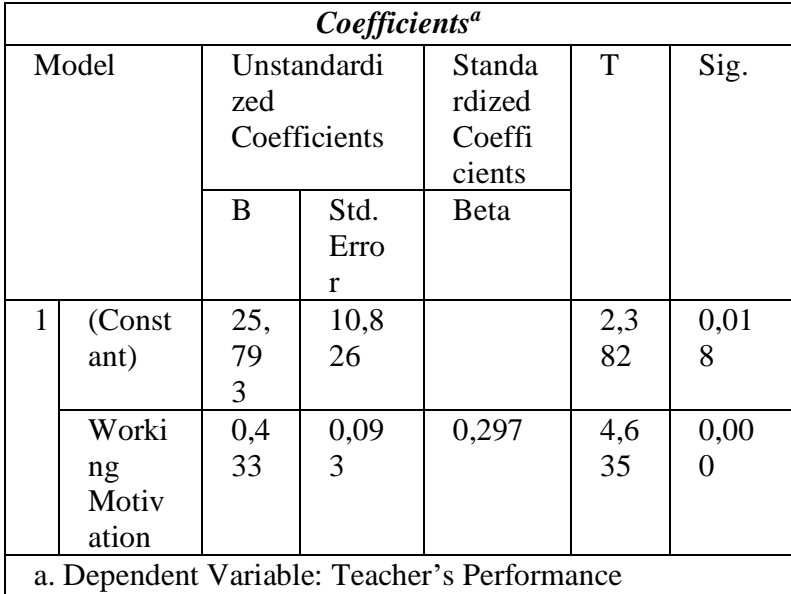

So, it can be interpreted that if work motivation has a zero significance value, the performance of the SD Negeri Makarti Jaya District teacher will be constant at 25.793. If work motivation contributes 0.433 , it will affect teacher performance by one unit. Thus, the questionnaire used in this study can be used to predict an increase in teacher performance on a linear line.

\section{CONCLUSION}

Based on the results of the research, it can be concluded that work motivation influences teacher performance. This situation shows that there is an effect of work motivation on teacher performance in SD Negeri Makarti Jaya District has answered the 
first hypothesis. Based on the conclusions of the research results, the researcher proposes several suggestions that can be put forward, namely that work motivation within a teacher should be able to arouse morale so that it can produce qualified teacher abilities.

\section{REFERENCES}

[1] Sutrisno. (2019). Human Resource Management. Jakarta: Golden.

[2] Mustafa, M.N. \& Othman, N. (2010). The Effect of Work Motivation on Teacher's Work Performance in Pekanbaru Senior High Schools, Riau Province, Indonesia. Sosiohumanika, 3(2).

[3] Mulyasa. (2006). Standar Kompetensi dan Sertifikasi Guru. Bandung: PT Remadja Rosda Karya.

[4] Sardiman. (2004). Belajar dan Pembelajaran. Jakarta: Rajawali Press.

[5] Mangkunegara. (2005). Company Human Resource Management. Bandung: PT Remaja Rosdakarya.

[6] Suryati., Harapan, E., Houtman. (2020). Effect of Work Motivation and Work Climate on Teacher' Performance. International Journal of Progressive Sciences and Technologies (IJPSAT). Vol. 20 No. 2 May 2020, pp. 137144. https://ijpsat.ijsht-journals.org/index.php/ ijpsat/article/view/1774/989

[7] Sulistiya, M. (2013). Pengaruh Kepemimpinan Kepala Sekolah Terhadap Kinerja Guru. Jurnal Ilmiah Pendidikan Ekonomi IKIP Veteran Semarang. Vol. 1 No. 2. 19-28 https://www.neliti.com/id/publications/37067/p engaruh-kepemimpinan-kepala-sekolahterhadap-kinerja-guru

[8] Elpisah., \& Hartini. (2019). Principal Leadership Style and Its Effect on Teachers Performance. Jurnal Aplikasi Manajemen, Volume 17, Number 3, Pages 506-514. Malang: Universitas Brawijaya. http://dx.doi.org/10.21776/ub.jam. 2019.017.03.15

[9] Baharuddin., \& R. Zakaria. (2018). Pengaruh Kecerdasan Spiritual Terhadap Peningkatan Teacher's performance di SMA Negeri 3 Takalar District Takalar. Jurnal Idaarah, Volume. 2, Nomor. 1, Pages 1-10. http://journal.uin-alauddin.ac.id/index.php/ idaarah/article/download/5071/pdf

[10] Inayatullah, A. \& Jehangir, P. (2012). Teacher's Job Performance: The Role of Motivation. Abasyn Journal of Social Sciences Vol. 5 No. 2, 78-99. http://ajss.abasyn.edu.pk/admineditor /papers /V5I2-6.pdf 